\title{
THE SEISMICITY AND TECTONICS OF THE MACQUARIE RIDGE
}

\author{
by T.D. Jones and K.F. McCue
}

(with two tables and four text-figures)

JONES, T.D. \& McCUE, K.F., 1988 (viii): The seismicity and tectonics of the Macquarie Ridge. Pap. Proc. $R$.

Soc. Tasm., 122(1): 51-57. Papers presented at the Macquarie Island Symposium, Hobart, May 1987. https://doi.org/10.26749/rstpp.122.1.51 ISSN 0080-4703. Australian Seismological Centre, Bureau of Mineral Resources, G.P.O. Box 378, Canberra, A.C.T., Australia 2601.

The Macquarie Ridge extends over $1200 \mathrm{~km}$ from southern New Zealand to a triple junction of the Pacific, Australian and Antarctic plates near $61^{\circ} 30^{\prime} \mathrm{S}, 161^{\circ} 00^{\prime} \mathrm{E}$. Large earthquakes occur frequently on the ridge, with an average return period of one year for an event of magnitude 6.2 or more and 10 years for one of magnitude 7.2 or more Analysis of 16 focal mechanism solutions indicates that the direction of the principal stress is consistently horizontal, and along the northern and central ridge segments it strikes east-west. In the southern ridge segment, its azimuth is poorly defined but appears to rotate towards the northeast with increasing southerly latitude. North of $51^{\circ} \mathrm{S}$, the characteristic fault displacement is along reverse dip-slip faults, whilst south of $51^{\circ} \mathrm{S}$, fault motion is predominantly by right-lateral strike-slip; throughout, the strike direction is parallel to the ridge axis.

Key Words: Macquarie Ridge, earthquakes, strike-slip, seismicity.

\section{INTRODUCTION}

The Macquarie Ridge marks the southernmost boundary between the Australian and Pacific lithospheric plates. It extends south from New Zealand to the triple junction at about $61^{\circ} 30^{\prime} \mathrm{S}$, $161^{\circ} 00^{\prime} \mathrm{E}$, where these two plates abut against the Antarctic plate (Falconer 1972). The ridge is a complex topographic structure (fig. 1, from Hayes \& Talwani 1972) in juxtaposition with a trench system which cuts through it at about $50^{\circ} \mathrm{S}$ and $56^{\circ} \mathrm{S}$, neatly subdividing it into northern, central and southern segments. At its northern end, the ridge is separated from the continental (?) Campbell Plateau to the east by the Solander Trough, with the Puysegur Trench extending from $46^{\circ} \mathrm{S}$ to $49^{\circ} \mathrm{S}$ to the west. The central ridge, which is narrow and flanked in the east by the Macquarie Trench, rises above sea level at $54^{\circ} 30^{\prime} \mathrm{S}$, at Macquarie Island, and can be traced from $51^{\circ} \mathrm{S}$ to $56^{\circ} \mathrm{S}$. The southern ridge segment is a broad feature, sloping gently eastward to the Emerald basin and separated from the Australian-Antarctic Rise in the west by the Hjort Trench which stretches from $56^{\circ} \mathrm{S}$ to $60^{\circ} \mathrm{S}$ (Hayes \& Talwani 1972). Cross sections showing the varying morphology through the three ridge segments are shown in figure 2 .

Associated with the Macquarie Ridge system is a narrow belt of shallow seismicity of moderately high activity (Gutenberg \& Richter 1954). Epicentres of the early earthquakes were located from Australian and New Zealand data, but since 1950 a seismograph has been operated at Macquarie Island by the Australian Bureau of Mineral Resources (BMR), and the antarctic network too has slowly been extended. This improvement in the regional seismograph network has resulted in more accurate epicentral determinations and a database sufficient to compute focal mechanisms from first motion data.

\section{SEISMICITY}

We have used hypocentres from the International Seismological Centre (ISC) supplemented with data from the BMR datafile, the DSIR in Wellington, and the United States Geological Survey and its predecessors. They span the years 1960, which was the year that heralded the introduction of the Worldwide Standardised Seismographic Network (WWSSN) and the consequent dramatic improvement in precision of hypocentral parameters, up to the end of 1984. Hypocentres of earthquakes 1918 to 1959 are from Gutenberg \& Richter (1954) and those from 1960 are from the International Seismological Summary (ISS).

The historical record is very scanty, with human habitation of Macquarie Island limited to occasional visits by sealers or shipwrecked mariners prior to 1948 when the Australian National Antarctic Research Expedition established a base there. Probably the earliest report is of a series of violent earthquakes commencing on 31 October 1815, with aftershock activity continuing to April 


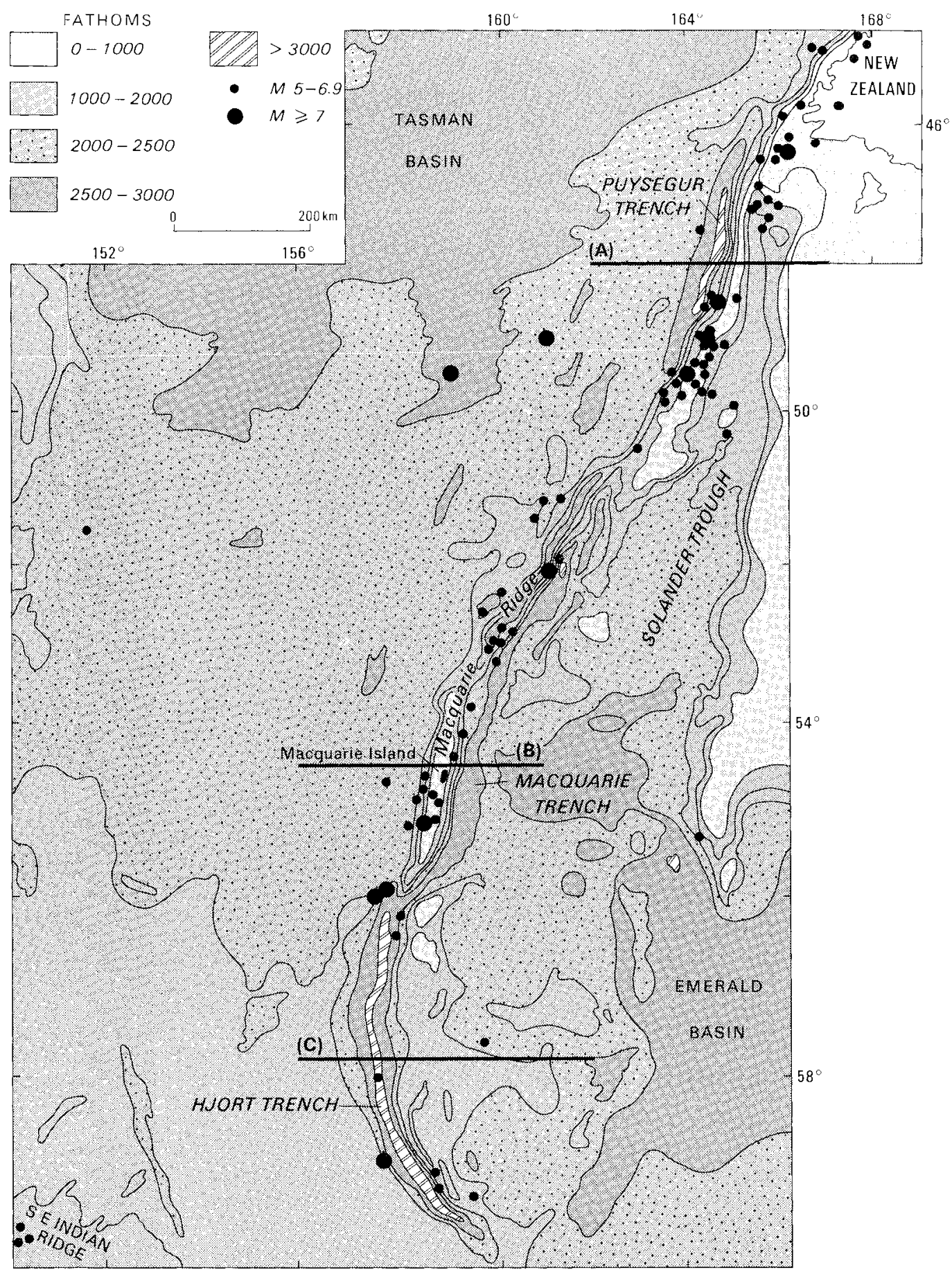

FIG. I - Topography and seismicity of the Macquarie Ridge. Earthquake epicentres are represented by the dots, the size indicating the magnitude. 
1816 (Sydney Gazette, 22 June 1816). The main shock is reported to have overthrown rocks and given the ground a wave-like motion for some seconds, several men being thrown off their legs and one considerably hurt. Another sealer claimed he witnessed the fall of several mountains and the rocking of others, which seemed to have separated from the summit to the base. The precise epicentre and magnitude cannot of course be determined, but the duration of the aftershock sequence and the fact that such a long aftershock sequence was felt at all implies that the main shock had to be of magnitude 6 or above and must have occurred very close to $\mathrm{M}$ acquarie Island.

It is interesting to compare this with a more recent report. Extensive ground deformation was observed around the shores of Macquarie Island following the 7 February 1980 earthquake of magnitude 6.5. There were extensive rock falls and mudslides and widespread ground fractures up to $15 \mathrm{~m}$ long and $0.5 \mathrm{~m}$ deep, the largest wide enough to walk in (Ledingham 1981). Earthquakes were reported felt through to mid-October. Allowing for the difference in time and writing style between these two reports, the effects seem to be fairly similar, so the earthquakes were probably of a similar size and similarly located near the island.

Figure 1 shows epicentres for events of magnitude 5.0 or more. With few exceptions the epicentres of the post-1964 events form a single narrow band only a few tens of kilometres wide, which is within the locatable error. The focal depths are poorly constrained but, from the appearance of the seismograms, the foci appear to be very shallow and probably limited to the crust, which (according to Williamson \& Johnson 1974) is less than $15 \mathrm{~km}$ thick under the central ridge segment. Common seismological practice was to assign a depth of $33 \mathrm{~km}$, later $10 \mathrm{~km}$, to earthquakes with obviously shallow but unconstrained depths, because of a lack of close seismograph stations. Both Sexton (1981) and Davies (1983) tabulated $\mathrm{S}-\mathrm{P}$ times for local earthquakes recorded at Macquarie Island and found a significant number in the $\mathrm{S}-\mathrm{P}$ range of $0-3 \mathrm{sec}$, corresponding to focal distances of 0 to about $20 \mathrm{~km}$ and indicating that at least some of the earthquakes are very shallow.

In the northern and central segments, earthquakes largely occur within the ridge rather than under the trench but this pattern is not so evident in the southern segment, where the relatively few epicentres occur beneath or near the Hjort Trench.

There is a low level of background seismicity off the ridge, commensurate with normal intraplate activity.
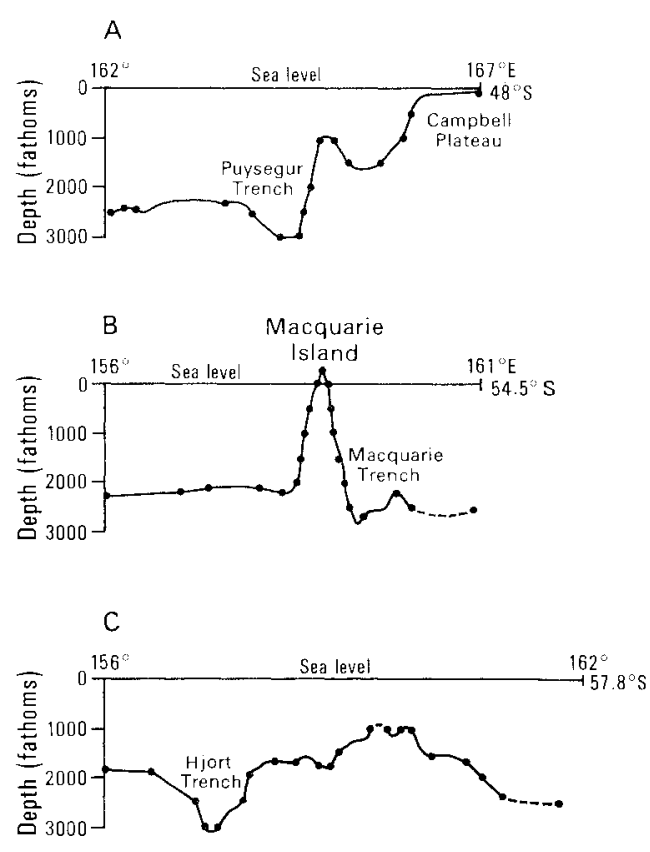

FIG. 2 - Topographic cross sections across the north, central and south segments of the Macquarie Ridge.

The greatest activity currently occurs near the southern end of the northern ridge segment. In marked contrast, immediately to the south, where the trench cuts the ridge, there has been an almost complete absence of seismicity in the past quartercentury.

The central ridge is marked by seismicity which is evenly distributed along its $500 \mathrm{~km}$ length, in contrast with the southern segment, where recent earthquakes are sparse but relatively large in magnitude. The lack of smaller events is not just a symptom of the poor seismographic coverage, since there were many small events in this period located farther southeast of the Hjort Trench, beyond the triple junction.

Epicentres of the 12 largest earthquakes (table 1) which have occurred along the length of the ridge since 1918 are marked by the large dots in figure I. Some of the epicentres are more than $100 \mathrm{~km}$ off the ridge axis, but this distance is within the uncertainty in the epicentres and the earthquakes probably occurred along the ridge axis, though where on the ridge is impossible to determine. 


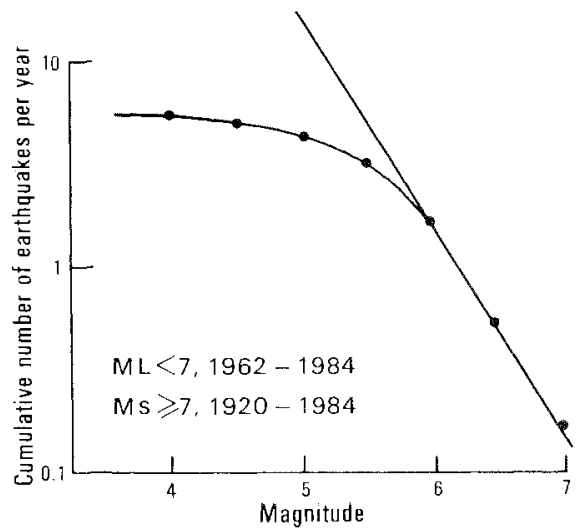

FIG. 3 - Recurrence relation for Macquarie Ridge earthquakes.

\section{MAGNITUDE RECURRENCE RELATIONS}

A plot of the cumulative frequency of earthquakes versus magnitude, for the ridge segment bounded by $47^{\circ}-61^{\circ} \mathrm{S}$ and $155^{\circ}-165^{\circ} \mathrm{E}$, is shown in figure 3 . The data cover the years 1962-84 for magnitudes less than Ms 7.0 and 1920-84 for magnitudes greater than or equal to Ms 7.0 (table 1). The linear portion of the plot yields a "b" value (slope) of $0.97( \pm 0.02)$. On average, the once-a-year earthquake has a magnitude of Ms 6.2, the 10-year earthquake a magnitude of Ms 7.2 and the extrapolated 100-year earthquake a magnitude of $\mathrm{Ms}$ 8.2. The largest earthquakes this century (table 1) occurred in 1924 and 1943 and were of magnitude Ms 7.8.

A significant feature of the recurrence relation is the relatively small number of moderate earthquakes located for the period 1962 84. We interpret this flattening of the recurrence curve to mean that some earthquakes in that period up to a Richter magnitude of 5.5 were not located; hypocentres appear in the bulletins for only half of the expected number of earthquakes of magnitude 5. This situation probably continues to the present day, due to the scarcity of sensitive seismographs in the southwest Pacific and Antarctica.

\section{FAULT PLANE SOLUTIONS}

In table 2, details are given of the 16 earthquakes for which fault plane solutions have been determined. The greatest and least principal stress axes are assumed to act at angles of $45^{\circ}$ to the nodal planes. In addition to those already published, the

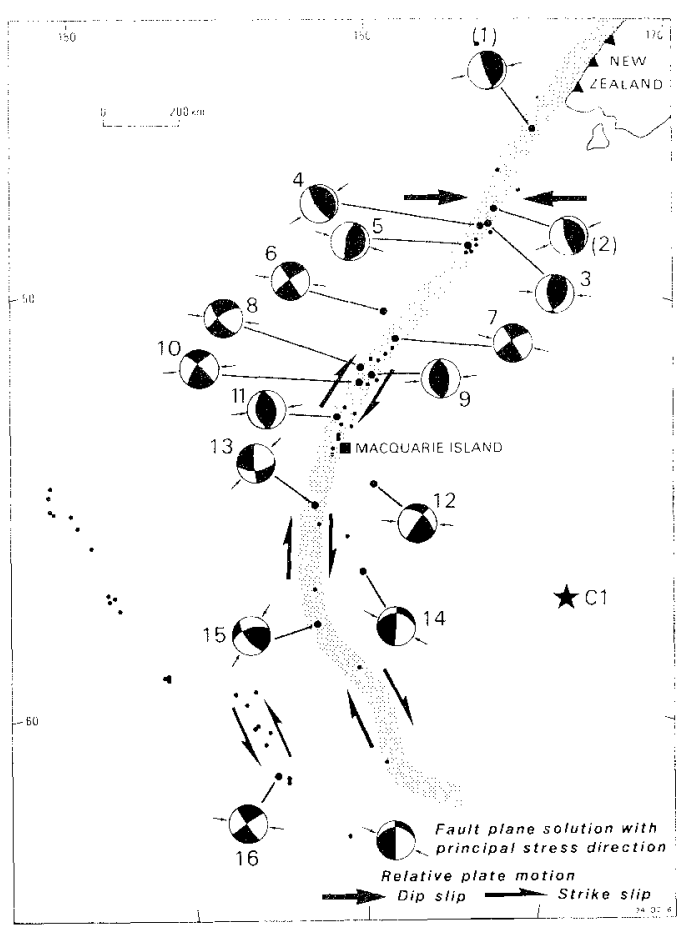

FIG. 4 - Fault plane solutions. The numbers coincide with those in table 2.

authors have drawn up an additional six fault plane solutions from the ISC bulletins for earthquakes that have occurred since the inception of the WWSSN. All events lie on the Macquarie Ridge, except for event 16 which is located on the transform fault between the Australian and Antarctic plates, near the triple junction.

The five solutions (fig. 4, events 1-5) for the northern Macquarie Ridge section include one for the Puysegur Bank earthquake of 12 October 1979 , which was felt widely through the southern island of New Zealand. All five are east-west thrust mechanisms, as is that for 31 January 1985, off the southwest coast of New Zealand (ISC Bulletin, January 1985); the mean azimuth for the pressure axis is $257^{\circ}$ and the mean plunge $27^{\circ}$. In four of the five cases, one of the nodal planes dips at a shallow angle in an approximately easterly direction, and in all five cases the complementary nodal plane dips steeply in an approximately westerly direction.

The six solutions (events 6-11) for the central ridge section have remarkably similar directions for the pressure axis, with a mean value azimuth of 
TABLE 1

Major earthquakes along the Macquarie Ridge

\begin{tabular}{|c|c|c|c|c|c|c|c|c|}
\hline \multicolumn{3}{|c|}{ Date } & \multicolumn{2}{|c|}{ Time } & \multirow{2}{*}{$\begin{array}{l}\text { Latitude } \\
{ }^{\circ} \mathrm{S}\end{array}$} & \multirow{2}{*}{$\begin{array}{c}\text { Longitude } \\
{ }^{\circ} \mathrm{E}\end{array}$} & \multirow{2}{*}{$\begin{array}{c}\text { Depth } \\
\text { km }\end{array}$} & \multirow[t]{2}{*}{ Mag.* } \\
\hline $\mathbf{y}$ & $\mathbf{m}$ & $\mathbf{d}$ & $\mathbf{h}$ & $\mathbf{m}$ & & & & \\
\hline 1924 & 06 & 26 & 01 & 37 & 56 & 157.5 & 33 & 7.8 \\
\hline 1924 & 07 & 24 & 04 & 55 & 49.5 & 159 & 50 & 7.5 \\
\hline 1926 & 10 & 03 & 19 & 38 & 49 & 161 & 50 & 7.5 \\
\hline 1936 & 02 & 22 & 15 & 31 & 49.5 & 164 & 33 & 7.2 \\
\hline 1943 & 09 & 06 & 03 & 41 & 55.1 & 158.5 & 0 & 7.8 \\
\hline 1960 & 12 & 13 & 07 & 36 & 52.09 & 161.04 & 0 & 7.1 \\
\hline 1964 & 09 & 12 & 22 & 07 & 48.95 & 164.46 & 33 & $(7.0)$ \\
\hline 1965 & 08 & 02 & 13 & 19 & 55.90 & 157.70 & 33 & (7.1) \\
\hline 1970 & 06 & 11 & 16 & 46 & 58.86 & 157.60 & 33 & 7.2 \\
\hline 1979 & 10 & 12 & 10 & 25 & 46.54 & 165.91 & 33 & 7.2 \\
\hline 1981 & 05 & 25 & 05 & 25 & 48.55 & 164.70 & 0 & 7.4 \\
\hline 1982 & 07 & 07 & 10 & 43 & 51.15 & 160.64 & 10 & 7.0 \\
\hline
\end{tabular}

* Magnitudes are surface-wave Ms. (7.0) implies Ms computed from body-wave magnitude MB.

TABLE 2

Fault plane solutions for Macquarie Ridge earthquakes*

\begin{tabular}{|c|c|c|c|c|c|c|c|c|c|c|c|c|}
\hline \multirow[t]{2}{*}{ No. } & \multicolumn{3}{|c|}{ Date } & \multicolumn{2}{|c|}{ Time } & \multirow[t]{2}{*}{ Lat. } & \multirow[t]{2}{*}{ Long. } & \multirow[t]{2}{*}{ Depth } & \multirow[t]{2}{*}{ Mag. } & \multicolumn{2}{|c|}{ Principal Stress Axes } & \multirow[t]{2}{*}{ Source $^{* *}$} \\
\hline & $\mathbf{y}$ & $\mathbf{m}$ & d & $\mathbf{h}$ & $\mathbf{m}$ & & & & & $\begin{array}{l}\mathbf{p} \text { axis } \\
\mathbf{p l} / \mathbf{a z}\end{array}$ & $\begin{array}{l}t \text { axis } \\
\text { pl/az }\end{array}$ & \\
\hline 1 & 1979 & 10 & 12 & 10 & 25 & 46.54 & 165.91 & 33 & 7.2 & $34 / 251$ & $54 / 049$ & 4 \\
\hline 2 & 1981 & 05 & 25 & 05 & 25 & 48.55 & 164.70 & 0 & 7.4 & $27 / 241$ & $62 / 080$ & 1 \\
\hline 3 & 1964 & 09 & 12 & 22 & 07 & 48.95 & 164.46 & 33 & $6.1 \mathrm{MB}$ & $17 / 274$ & $73 / 004$ & 2 \\
\hline 4 & 1964 & 11 & 08 & 02 & 43 & 48.98 & 164.20 & 33 & $5.6 \mathrm{MB}$ & $28 / 236$ & $62 / 056$ & 3 \\
\hline 5 & 1967 & 09 & 20 & 09 & 39 & 49.57 & 163.93 & 34 & $5.8 \mathrm{MB}$ & $27 / 281$ & $63 / 101$ & 6 \\
\hline 6 & 1982 & 07 & 07 & 10 & 43 & 51.15 & 160.64 & 10 & 7.0 & $08 / 101$ & $07 / 193$ & 1 \\
\hline 7 & 1984 & 05 & 23 & 05 & 16 & 51.88 & 161.08 & 10 & 5.8 & $05 / 100$ & $02 / 192$ & 1 \\
\hline 8 & 1969 & 06 & 17 & 23 & 58 & 52.53 & 159.70 & 33 & 6.6 & $27 / 098$ & $02 / 006$ & 1 \\
\hline 9 & 1966 & 05 & 25 & 13 & 20 & 52.77 & 160.17 & 33 & $6.0 \mathrm{MB}$ & $09 / 078$ & $81 / 258$ & 8 \\
\hline 10 & 1979 & 04 & 23 & 21 & 54 & 52.93 & 159.84 & 10 & 6.0 & $05 / 089$ & $20 / 181$ & 1 \\
\hline 11 & 1977 & 07 & 21 & 11 & 53 & 53.82 & 158.84 & 33 & 6.7 & $00 / 084$ & $89 / 347$ & 4 \\
\hline 12 & 1982 & 06 & 27 & 16 & 17 & 55.42 & 160.23 & 10 & 6.2 & $26 / 271$ & $35 / 161$ & 5 \\
\hline 13 & 1965 & 08 & 02 & 13 & 19 & 55.90 & 157.70 & 33 & $6.2 \mathrm{MB}$ & $26 / 051$ & $16 / 313$ & 8 \\
\hline 14 & 1963 & 05 & 12 & 09 & 43 & 57.56 & 159.78 & 33 & 6.4 & $35 / 116$ & $39 / 240$ & 6 \\
\hline 15 & 1970 & 06 & 11 & 16 & 46 & 58.86 & 157.60 & 33 & 7.2 & $07 / 201$ & $43 / 107$ & 1 \\
\hline 16 & 1983 & 04 & 27 & 01 & 39 & 62.50 & 155.30 & 10 & 5.9 & $07 / 105$ & $01 / 015$ & 7 \\
\hline
\end{tabular}

* Magnitude is Ms (surface-wave scale) or MB (body-wave scale). Time is Universal Time, hypocentres are from the ISC or ISS.

** Focal mechanism sources are (1) Jones \& McCue, this paper; (2) Sykes (1967); (3) Denham (1977);

(4) Giardini et al. (1985); (5) Dziewonski et al. (1983); (6) Johnson \& Molnar (I972); (7) ISC; (8) Banghar \& Sykes (1969). 
$92^{\circ}$ and a mean plunge of $9^{\circ}$. Solutions $6,7,8$ and 10 are almost pure strike-slip, and solutions 9 and 11 are pure east-west thrust mechanisms.

Earthquake 12 occurred some $100 \mathrm{~km}$ east of the trench crossover which separates the central and southern ridge sections, and its mechanism is dominantly strike-slip, similar to the strike-slip mechanisms of earthquakes on the central ridge.

Earthquakes 13 and 15 seemingly occurred beneath the Hjort Trench, the axis of which rotates increasingly counterclockwise in the south. The mechan ism for each contains a strong component of strike-slip motion, with one of the nodal planes striking parallel to the trench axis; the direction of the pressure axis for the more southerly event (15) is accordingly northnortheast compared to the northeast direction of the pressure axis for event 13 .

Earthquake 14 occurred in the eastern part of the broad southern ridge and its fault plane solution is a combination of thrust faulting at $116^{\circ}$, and of strike-slip faulting. However, while the direction of thrust faulting is approximately east-west, in agreement with other thrust mechanisms along the ridge, the strike-slip component in the mechanism implies a sense of movement opposite to that of the other strike-slip mechanism, i.e. left-lateral slip along the ridge axis rather than right-lateral slip, if slip occurs along the nodal planes parallel to the ridge axis.

The focal mechanism for the earthquake of 27 April 1983 (event 16), which occurred on the Balleny Fracture Zone, resembles closely the strike-slip mechanisms of the central ridge, with a pressure axis almost east-west.

\section{DISCUSSION}

At least along the northern and central Macquarie Ridge the foci are under the ridge rather than the parallel trench. The epicentres form a single, rather narrow band until well south of Macquarie Island, where earthquakes are apparently less frequent than in the north, although the location capability decreases with distance south along the ridge.

There is some suggestion that the trenchridge crossover points mark the places where the largest earthquakes have occurred this century, yet over the last 25 years there has been a relative lack of small and moderate earthquakes. They may be sites where either the accumulating stress is lower than in the neighbouring ridge segments because it has been released by previous large earthquakes, or where the stress level is higher but so also is the crustal strength.
Our ability to decide between the two choices is limited by the uncert ainty in position of the large earthquakes earlier in the century, but the question may be clarified by an analysis of slippage rates along the ridge, which can be calculated from estimated fault dimensions of the largest recent earthquakes.

More frequent seismicity accounts for stress release along the northern and, in particular, the central Macquarie Ridge segments. The level of seismicity is lower along the southern ridge segment than the northern segments, possibly due to its position relative to the pole of rotation of the Pacific plate.

The lack of moderate or deep seismicity indicates that no well-developed subduction process exists. Perhaps the onset of subduction has only recently begun, analogous to the plate boundary along the northwest coast of the United States where there is also an absence of subcrustal seismicity. In the Fiordland region of New Zealand, there is active subduction of the Australian plate (Christoffel \& van der Linden 1972); st udies by the authors with P.E. Williamson, suggest that in the central Macquarie Ridge the Australian plate has been foreshortened and thickened by approximately $65 \mathrm{~km}$ in a process preceding subduction.

The frequency of large earthquakes is quite high, with average return periods of 1 and 10 years for earthquakes of magnitude 6.2 and 7.2 respectively. The slope of the recurrence relation " $b$ " is $0.97( \pm 0.02)$. The decrease in "b" with decreasing magnitude suggests that some earthquakes, even up to magnitude 5.5 , are not being located.

We interpret the fault plane solutions in the following way. In the northern Macquarie Ridge segment, where the trench is to the west of the ridge, the nodal plane which dips shallowly east could represent a fault plane on which subduction has recently begun in a similar sense to that off the southwest coast of New Zealand.

In the central ridge segment, thrust events have both nodal planes striking along the ridge, and either one could be the fault plane. For the strike-slip solutions, the nodal plane paralleling the ridge is probably the fault plane, in which case the sense of motion is right-lateral.

In the southern ridge segment, the fault planes also lie along the ridge axis, and so the inferred mechanisms are again strike-slip in a rightlateral sense. Hence, there is a consistent regime of right-lateral strike-slip motion, albeit with some element of east-west thrusting, along the ridge from about latitude $51^{\circ} \mathrm{S}$ to the triple junction.

If we choose the nodal plane parallel to the 
transform fault as the fault plane for event 16 , then the motion is left-lateral strike-slip, which is consistent with the motion on the transforms along the south-Indian and Pacific Ocean spreading centres.

The only inconsistent mechanism is that for event 14 and the solution has not been re-examined. This earthquake occurred in May 1963, before the completion of the World Standard seismograph network, and it is possible that few data were available to determine its mechanism.

\section{CONCLUSIONS}

From the fault plane solutions we infer that movement along the ridge is consistent with an anticlockwise rotation of the Pacific plate, relative to the Australian plate, about a pole located east of the central or south Macquarie Ridge and within some $1000 \mathrm{~km}$ of the ridge, as suggested by other authors (C1 in fig. 4 from Christoffel \& van der Linden 1972, Minster \& Jordan 1978, Johnson \& Molnar 1972). Such a rotation would account for the compressive regime producing subduction in Fiordland, New Zealand, possible incipient subduction beneath the northern Macquarie Ridge, and the combination of right-lateral strike-slip and east-west thrusting observed in the central Macquarie Ridge. It is also consistent with the observed right-lateral strike-slip regime in the south Macquarie Ridge section, which continues southeast to the triple junction.

\section{ACKNOWLEDGEMENTS}

We wish to thank Natasha Kozin and Brian Pashley who drafted the figures, James Lewis who compiled much of the data, and Leonie Jones who offered many useful suggestions.

\section{POSTSCRIPT}

On 3 September 1987, at 0640 UT, a major earthquake occurred beneath the Hjort Trench at approximately $59^{\circ} 12^{\prime} \mathrm{S}, 158^{\circ} 18^{\prime} \mathrm{E}$. It was a shallow earthquake and the surface wave magnitude was around 7.3. The fault plane solution for this event will give additional control on the tectonic regime in the southern ridge area.

(accepted 5 January 1988)

\section{REFERENCES}

BANGHAR, A.R. \& SYKES, L.R., 1969: Focal mechanisms of earthquakes in the Indian Ocean and adjacent regions. J. Geophys. Res., 74(2): $632-649$.

CHRISTOFFEL, D.A.\& VAN DER LINDEN, W.J.M., 1972: Macquarie Ridge-New Zealand Alpine Fault transitions. In Hayes, D.E. (Ed ) ANTA RCTIC OCEA NOLOGY II: THE A USTRALIAN-NEW ZEALAND SECTOR. Antarctic Research Series, 19: 235-242.

DAVIES, P.M., 1983: Macquarie Island Geophysical Observatory Annual Report. Bur. Min. Resour. Rec. 83(2): $39 \mathrm{pp}$.

DENHAM, D., 1977: SUMMARYOF EARTHQUAKE FOCAL MECHANISMS FOR THE WESTERN PACIFIC-INDONESIAN REGION, 1929-1973. Report SE-3, World Data Centre A for Solid Earth Geophysics: 110 pp.

DZIEWONSKI, A., FRIEDMAN, A., GIARDINI, D. \& WOODHOUSE, J.H., 1983: Global seismicity of 1982: centroid-moment tensor solutions for 308 earthquakes. Phys. Earth Planet. Inter., 33: $76-90$.

FALCONER, R.K.H., 1972: The Indian-AntarcticPacific triple junction. Earth Planet. Sci. Lett., 17: $151-158$

GIARDINI, D., DZIEWONSKI, A.\& WOODHOUSE, J., 1985: Centroid-moment tensor solutions for 113 large earthquakes in 1977-1980. Phys. Earth Planet. Inter., 40: 259-272.

GUTENBERG, B. \& RICHTER, C.F., 1954. SEISMICITY OF THE EARTH. Princeton University Press: 310 pp.

HAYES, D.E. \& TALWANI, M., 1972: Geophysical investigations of the Macquarie Ridge Complex. In Hayes, D.E. (Ed.): $A N T A R C T I C O C E A N$ OLOG Y II: THE AUSTRA LIAN-NEW ZEA$L A N D S E C T O R$. Antarctic Research Series 19: 211-234.

INTERNATIONAL SEISMOLOGICAL CENTRE, 1961-84: Bulletin of the International Seismological Centre, 1(1)-21(12).

JOHNSON, T. \& MOLNAR, P., 1972: Focal mechanisms and plate tectonics of the southwest Pacific. J. Geophys. Res., 77(26): 5000-5032.

LEDINGHAM, R., 1981: Macquarie shakes again, Aurora, October 1981:6-8

MINSTER, J.B. \& JORDAN, T.H., 1978: Present day plate motions. J. Geophys. Res., 10: $5331-5334$.

SEXTON, M.J., 1981: Macquarie Island Geophysical Observatory Annual Report. Bur. Min. Resour. Rec., 81(17): 23 pp.

SYKES, L.R., 1967: Mechanisms of earthquakes and nature of faulting on the mid-oceanic ridges. $J$. Geophys. Res., 72(8): 2131-2153.

WILLIAMSON, P. \& JOHNSON, B.D., 1974: Crustal structure of the central region of the Macquarie Ridge complex from gravity studies. Mar. Geophys. Res., 2: 127-132. 